\title{
Influence of soil microorganisms on metal corrosion of underground pipelines
}

\section{Vliv půdních organismů na korozi podzemních potrubí}

\author{
Polutrenko M. ${ }^{1}$, Maruschak ${ }^{2}{ }^{2}$, Tymoshenko A. ${ }^{3}$, Sorochak $A .^{2}$ \\ ${ }^{1}$ Ivano-Frankivsk National Technical University of Oil and Gas, Ukraine \\ ${ }^{2}$ Ternopil Ivan Pul'uj National Technical University, Ukraine \\ ${ }^{3}$ Open International University of Human Development, Ukraine \\ E-mail: Maruschak.tu.edu@gmail.com
}

There have been revealed and summarized the regularities in biocorrosion of steel $17 \mathrm{G} 1 \mathrm{~S}-\mathrm{U}$, which is traditionally used for manufacturing oil and gas mains. The basic regularities of biocorrosion processes in the $17 G 1 S$-U pipe steel under the influence of SRB Desulfovibrio Sp. strains Kyiv-10 was obtained by weight-loss testing and surface analysis techniques. Effective inhibitors are proposed, which allow protecting steel $17 G 1 S-U$ against the development of anaerobic corrosion under the influence of sulfate-reducing bacteria (SRB). The effectiveness of inhibitors is estimated by the degree of their protective effect. The porous structure of the surface film contributes to the initiation of localized corrosion. Damage analysis of the specimen surface corroded under different test conditions was performed.

\section{INTRODUCTION}

Providing reliability and reducing the accidents of underground pipelines in soils with different degrees of mineralization is an important scientific and production task $[1,2]$. It is known that one of the main factors that cause corrosion damage to metallic structures in soils is the effect of microorganisms (MOs) that use metal as a power source. At the same time, due to their activity, the $\mathrm{PH}$ of the medium changes causing fracture of the metal. About $80 \%$ of corrosion damage of the oilfield equipment takes place with the participation of MOs, among which the sulfate-reducing bacteria (SRB) play the leading role. At the same time, the use of bactericides to combat them is, as a rule, ineffective, because SRB are firmly fixed on metallic surfaces and form biofilms covered with slurry and products of corrosion [3-5]. It should be emphasized that the kinetics of biocorrosion can be different for different types of steels. This is due to the fact that some doping elements increase biocorrosive stability, but others are potential components of nutrition for bacteria. The grain morphology of steels also affects their corrosion resistance. As a rule, increasing the size of grains intensifies intercrystalline corrosion due to an increase in the length of their boundaries, which traditionally is a "weak point" of steels.
Byly studovány a zhodnoceny trendy $v$ biokorozi oceli $17 G 1 S-U$, která je běžně použivána pro výrobu petrochemických potrubí. Hlavni metodou studia biokoroznich procesů oceli ovlivněné sulfát redukujíci bakterii Desulfovibrio Sp. kmen Kyjev-10 bylo hodnoceni hmotnostnich úbytki a mikroskopie povrchu. Účinné inhibitory proti účinkưm této ananerobní bakterie byly nalezeny. byly vyhodnoceny efektivity inhibičního účinku. Porozita biofilmu přispivá k lokalizaci napadení. Byla provedena analýza poškození materiálu za rüzných podminek expozice.

Lithotrophic anaerobic SRB are very often isolated in the $\mathrm{H}_{2} \mathrm{~S}$ medium, which is the most dangerous of all known corrosion stimulants. In the presence of hydrogen sulfide, the metal is hydrogenated, which reduces its mechanical strength [1-8]. Underestimation of the danger of microbial corrosion causes premature failure of underground pipelines and the occurrence of extraordinary situations with severe environmental consequences $[2-3,10]$.

Thus, the objective of this research is to establish the basic regularities of biocorrosion processes in the $17 \mathrm{G} 1 \mathrm{~S}-\mathrm{U}$ pipe steel under the influence of SRB Desulfovibrio Sp. strains Kyiv-10.

On the outer surface of the gas main "Pasichna Tysmenytsia" (Fig. 1), multiple corrosive ulcers caused by the influence of biocorrosion are shown. Such defects are typical damage to the metal due to the formation of local sulfide deposits and microorganism colonies in the ground electrolyte in the presence of hydrogen sulfide of biogenic origin on the surface $[6,9]$. The unevenness of the surface damage should be noted, which confirms the localization of corrosion processes. This suggests that even small fluctuations in microbiocenosis affect the kinetics of damage to the metalwork. 


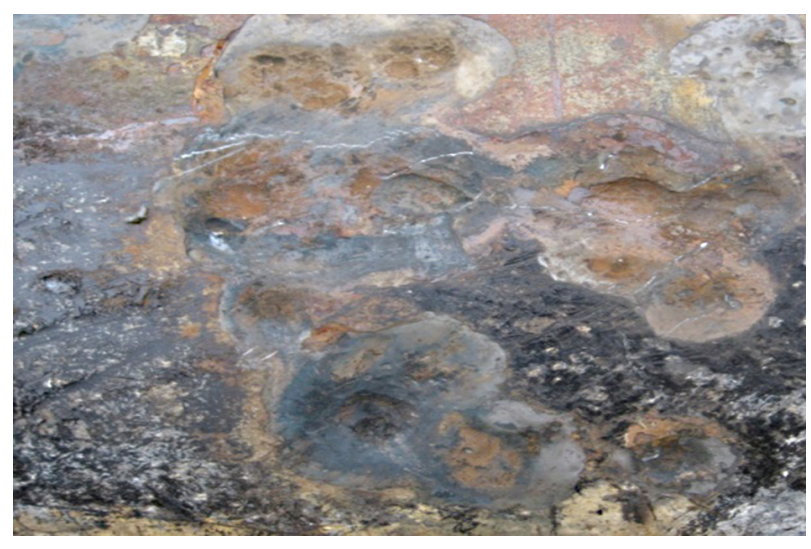

Fig. 1. Corrosion ulcers found on the wall of the gas main "Pasichna - Tysmenytsia"

Obr. 1. Korozní napadení pod biofilmem na stěně plynového potrubí "Pasichna - Tysmenytsia"

Therefore, in our opinion, it is reasonable to optimize the selection of insulating materials for gas main systems to facilitate the formation of microbiocenosis with high catalase activity, which assists in protection against biocorrosion.

\section{MATERIALS AND METHODS}

The objects of research were the model specimens from the $17 \mathrm{G} 1 \mathrm{~S}-\mathrm{U}$ pipe steel in the initial state, with the size of $10 \times 30 \times 1 \mathrm{~mm}$. The specimens were cut from the pipe, their working and lateral surfaces were milled. The specimen surface was not polished, since the gas main surface contains micro-roughness. In general, the preparation of specimens for the experimental research is similar to that described in [11].

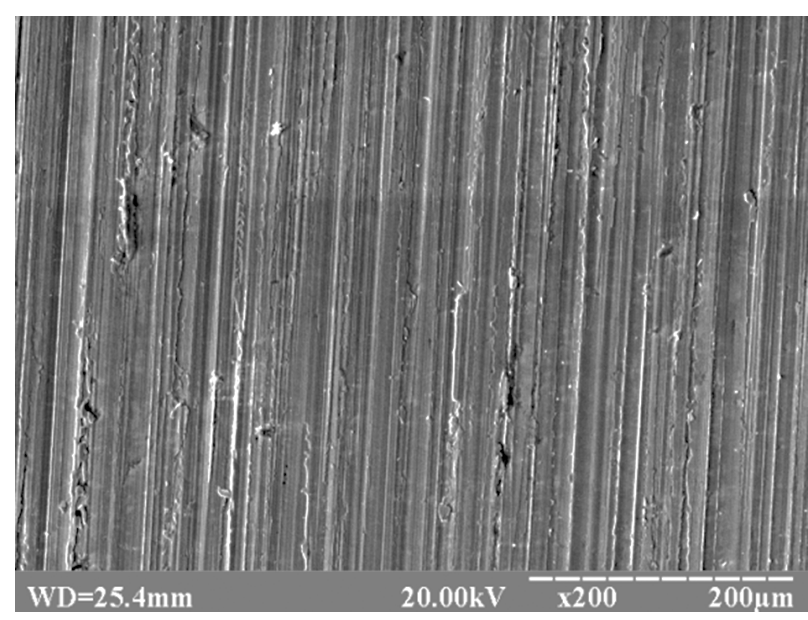

a)
SRB cells Desulfovibrio Sp. strains Kyiv-10 were grown in Postgate's B liquid medium [12] in a thermostat at a temperature of $28{ }^{\circ} \mathrm{C}$ for 14 days. Pure colonies of sulfate reducers were obtained in a semi-liquid Postgate's $B$ medium by inoculating a ten-fold dilution.

The schemes of experiments with additional introductions into the test system of inhibitors such as organic nitrogen-containing compounds were also investigated:

Inhibitor \# 1 - 1,8-dioxo-3,3,6,6,9-pentamethyl-10phenyl-1,2,3,4,5,6,7,8,9,10-decahydroacridine;

Inhibitor \# 2 - hexamethyldodecylammonium chloride.

The control medium was Postgate's B sterile nutrient medium for the cultivation of SRB bacteria. The exposure period of steel specimens was 62 days. Upon completion of the research, the metallic specimens were subjected to the mechanical and chemical treatment to remove corrosion products from their surface.

The corrosion rate of metallic specimens was determined by the gravimetric index of the corrosion rate $\left(K_{g r}\right)$ :

$$
K_{g r .}=\left(m-m_{0}\right)(S \cdot \tau)\left[\mathrm{mg} \mathrm{dm}^{-2} \text { day }\right],
$$

where $m$ is the final mass of the specimen, $\mathrm{mg} ; m_{0}$ is the specimen mass before corrosion, $\mathrm{mg} ; S$ is the surface area of the specimen, $\mathrm{dm}^{2} ; \tau$ is the exposure period, day.

The bactericidal properties of the inhibitors studied were determined according to the DSTU 3999-2000 [13]. The concentration of inhibitors was $0.5 \%$ and $1.0 \%$. The effectiveness of the inhibitors studied was characterized by the degree of protective action of inhibitors $(Z)$, calculated by the formula:

$$
Z=\left[\left(K_{g r}-K_{g r 1}\right) / K_{g r}\right] \cdot 100[\%]
$$

where $K_{g r}$ is the corrosion rate in the uninhibited medium, $\mathrm{mg} \mathrm{dm}{ }^{-2}$ day; $K_{g r 1}$ is the corrosion rate in the presence of inhibitors, $\mathrm{mg} \mathrm{dm}^{-2}$ day.

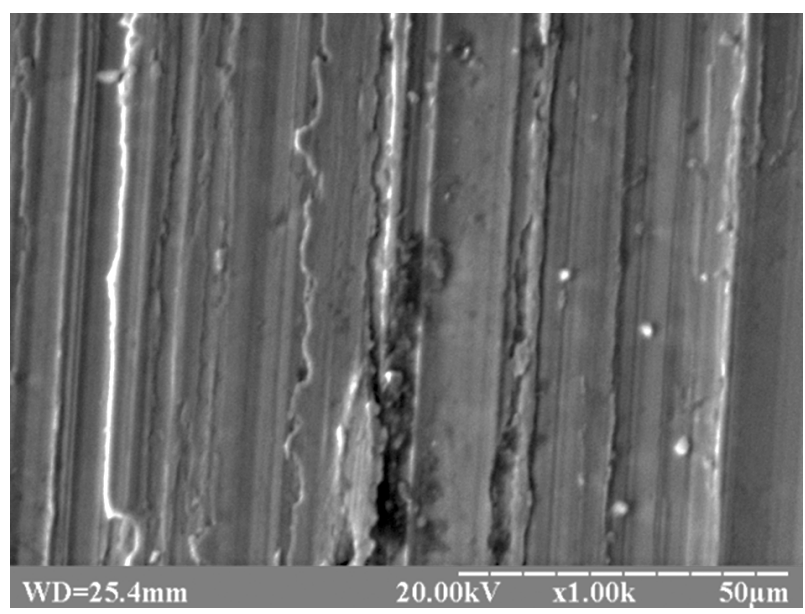

b)

Fig. 2. Surface morphology of steel $17 \mathrm{G} 1 \mathrm{~S}-\mathrm{U}$ at various magnifications in the initial state Obr. 2. Morfologie povrchu oceli v pưvodním stavu 
For microstructural and fractographic studies, the electron microscope REM-106I and raster electron microscopy methods were used.

\section{RESULTS AND DISCUSSION}

The analysis of findings of the experimental research into the growth suppression of SRB bacteria Desulfovibrio $s p$. strains Kyiv-10 in the course of model laboratory experiments showed that in the sterile Postgate's B medium, in the case of steel 17G1S-U, no corrosion traces were detected. The relative corrosion activity, Fig. 3b, was calculated by the formula:

$$
\lambda=\left[\left(K_{g r 0}-K_{g r b}\right) / K_{g r 0}\right] \cdot 100[\%]
$$

where $K_{g r 0}$ and $K_{g r b}$ is the corrosion rate in the A medium and in the studied $B, C, D, E, F$ media, respectively.

An increase in the corrosion rate in the case of test schemes B, C was found, indicating their significant biocorrosion activity: $\lambda_{B}=193.75 \%$ and $\lambda_{C}=206.25 \%$. For the test schemes $D, E, F$, a decrease in the corrosion rate was observed: $\lambda_{D}=31.25 \%, \lambda_{E}=87.50 \%$, and $\lambda_{F}=$ $81.25 \%$, respectively. The sign "_." in this case indicates that the biocorrosion rate of the steel $17 \mathrm{G} 1 \mathrm{~S}-\mathrm{U}$ in these media was lower than in the control $A$ medium.

\section{Without inhibitors}

In Postgate's B medium inoculated by SRB, the latter act as stimulators of the SRB growth activity, as evidenced by greater metal losses. The surface of the steel specimens was covered with a black precipitate, and the cloudiness of the corrosive medium was observed, indicating the development of biocorrosion with the participation of SRB, which caused the formation of biogenic sulfide of iron. When the specimens were dosed into the solution of hydrochloric acid, the sulfide film was destroyed with the release of hydrogen sulfide. As a result, specimens from the $17 \mathrm{G} 1 \mathrm{~S}-\mathrm{U}$ steel were corroded under the action of SRB.

\section{Effect of inhibitors 1 and 2}

For steel $17 \mathrm{G} 1 \mathrm{~S}-\mathrm{U}$, the addition to the medium of inhibitor \# 1 at a concentration of $0.5 \%$ caused the largest mass losses. This inhibitor at a concentration of $0.5 \%$ did not show the inhibitory effect, but, on the contrary, acted as a stimulant of the biocorrosion processes caused by SRB. By the end of the experiment, the growth rate of corrosion for the steel $17 \mathrm{G} 1 \mathrm{~S}-\mathrm{U}$ was observed to be $4-5 \%$. At the same time, an increase in the number of SRB cells was found, which may be due to the adaptation of SRB bacteria to the action of the toxicant (in particular, due to the adsorption of MOs on the steel surface with the formation of a protective biofilm), which led to the intensification of corrosion processes. A gradual increase in the number of SRB bacteria is probably due to the formation of metabolites, which are less toxic as compared to the initial inhibitor. It was found that an increase in the concentration of inhibitor \# 1 to $1.0 \%$ leads to the suppression of the sulfate-reducing activity. At the same time, the degree of metal protection against biocorrosion for steel $17 \mathrm{G} 1 \mathrm{~S}-\mathrm{U}$ amounted to $76,6 \%$.

At a concentration of $0.5 \%$, inhibitor \# 2 almost completely suppressed the growth of SRB. The degree of metal protection against corrosion, at the same time, was $95.74 \%$. With an increase in the concentration of inhibitor \# 2 in the nutrient medium up to $1.0 \%$, the effectiveness of inhibiting the growth activity of SRB somewhat

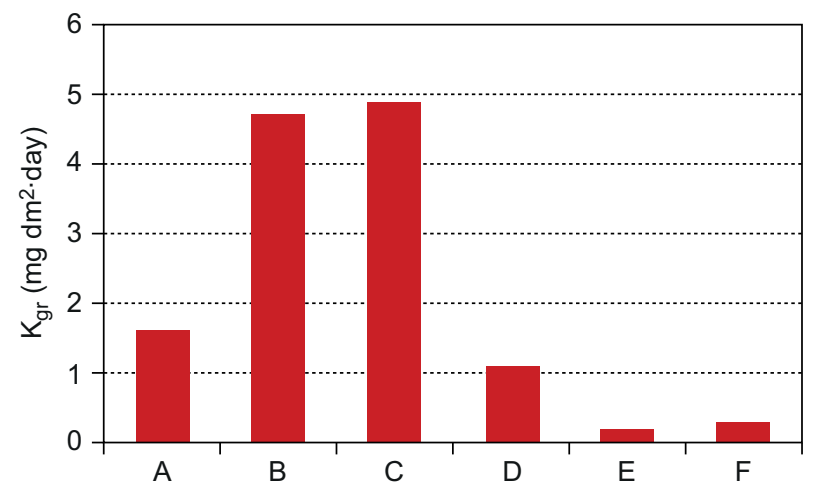

a)

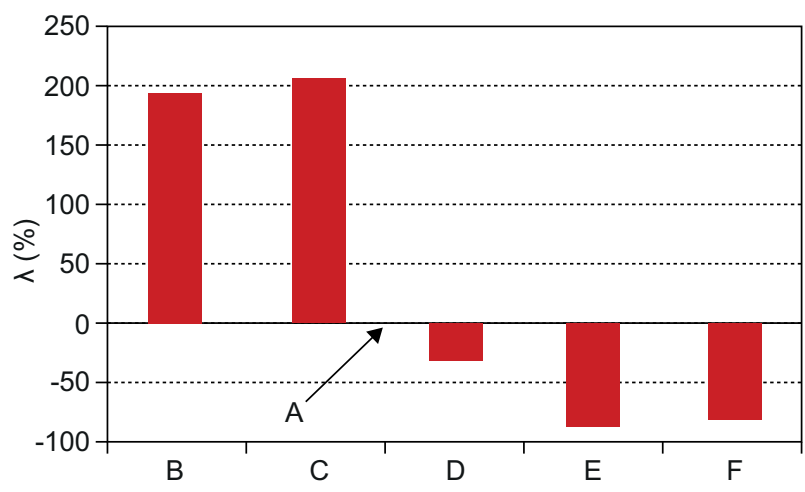

b)

Fig. 3. Corrosion rate of specimens from steel 17G1S-U in the presence of Desulfovibrio sp. strains Kyiv-10 in the following media: A - control A medium; B - Postgate's B medium + SRB; C - Postgate's B medium + SRB + inhibitor \# 1-0.5\%; D - Postgate's B medium + SRB + inhibitor \# 1-1.0\%; E - Postgate's B medium + SRB + inhibitor \# 2-0.5\%; F- Postgate's B medium + SRB + inhibitor \# 2-1.0\%

Obr. 3. Korozní rychlost vzorků v různých prostředích: $A$ - kontrolní medium $A ; B$ - Postgate $B$ medium $s$ prídavkem SRB; $C$ - Postgate $B$ medium s prídavkem SRB a 0,5\% inhibitoru 1; D - Postgate B medium s prídavkem SRB a 1,0\% inhibitoru 1; $E$ - Postgate $B$ medium s prídavkem SRB a 0,5\% inhibitoru 2; $F$ - Postgate B medium s prídavkem SRB a 1,0\% inhibitoru 2 
decreased, as evidenced by a decrease in the protective effect of the inhibitor to $93.62 \%$. Visual analysis of the specimen surface after the experiments showed that in the presence of inhibitor \# 2 at a concentration of $0.5 \%$ and $1.0 \%$ in the medium on the metal surface, no traces of corrosion were detected. In the presence of the investigated inhibitor, no cloudiness of Postgate's B medium was observed, no sulfide film was formed on the steel specimens, and a gray-black precipitate dropped to the bottom of tubes, indicating the death of a significant number of SRB cells and a slowdown in the process of biocorrosion of the steel. A high degree of the metal protection against the influence of SRB indicated the bactericidal properties of the investigated inhibitor. The results obtained are consistent with the results presented in [11].

Table 1 summarizes the data on the influence of the inhibitor nature on the degree of protection of steel $17 \mathrm{G} 1 \mathrm{~S}-\mathrm{U}$ against biocorrosion caused by SRB.

Tab. 1. The influence of the inhibitor nature on the degree of protection of steel 17G1S-U / Vliv typu inhibitoru na biokorozi oceli

\begin{tabular}{|c|c|c|c|}
\hline \multirow{2}{*}{ Steel } & Inhibitor & $\begin{array}{c}\text { Concentration } \\
\text { of inhibitor (\%) }\end{array}$ & $\begin{array}{c}\text { Protective } \\
\text { action } \mathbf{Z} \text { (\%) }\end{array}$ \\
\hline \multirow{3}{*}{ 17G1S-U } & - & - & 4.70 \\
\cline { 2 - 4 } & \multirow{2}{*}{1} & 0.5 & absent \\
\cline { 2 - 4 } & \multirow{2}{*}{2} & 1.0 & 76.60 \\
\cline { 2 - 4 } & & 0.5 & 95.74 \\
\hline
\end{tabular}

\section{Sem-analysis of the surface of corroded specimens}

\section{Without inhibitors}

It is found that for the test schemes $\mathrm{A}$ and $\mathrm{B}$, the surface of specimens from the $17 \mathrm{G} 1 \mathrm{~S}-\mathrm{U}$ steel was corroded, which is confirmed by the data on the mass loss of specimens. The surface of steel specimens acquired a black color due to biocorrosion with the participation of SRB.

\section{With inhibitors}

As noted above, inhibitor \# 1 intensified the corrosion process (test scheme $C$ ). On the surface of the specimens, Fig. 4a,b, "islets" with a length of 40-100 $\mu \mathrm{m}$ and a width of $50 \mu \mathrm{m}$ were found.
They have a random orientation that intersects the initial deformation relief at various angles. These islets have no clearly defined orientation and are merged into the network. The depressions between the islands were the sites of macrolocation of the corrosion process. Despite such "islet", corrosion developed quite uniformly in the depressions. According to the test scheme $(D)$, uniform corrosion damage was detected on the specimen surface along with several macro-ulcers with a length up to 100 $\mu \mathrm{m}$ and a width 20-30 $\mu \mathrm{m}$. Visually their depth varies slightly, the bottom is practically flat and covered with traces of corrosion, Fig. $4 \mathrm{~b}$.

The maximum inhibitory effect with suppressing the growth of SRB on specimens from the 17G1S-U steel was caused by inhibitor \# 2. Even when added at a concentration of $0.5 \%$ (test scheme $\mathrm{E}$ ), this inhibitor caused a reduction in corrosion, the specimen surface had only minor corrosion damage. The deformation relief of the analyzed surface, due to mechanical treatment, remained virtually in its original state, Fig. 4c.

According to the test scheme $(F)$, the corrosion resistance of the $17 \mathrm{G} 1 \mathrm{~S}-\mathrm{U}$ steel was insignificant. The surface is virtually in its initial state with individual microcorrosion damages, which manifested itself only in large increments, Fig. 4c. The results of the conducted studies indicate that an effective inhibitor of microbial corrosion of steel under the influence of SRB was inhibitor \# 2. The high protective effect of inhibitor \# 2, which is associated with quaternary ammonium salts, is probably due to the fact that, under microbial corrosion, a thin sulfide film is formed that is coated with a monomolecular layer of the inhibitor, which stops its further growth and inhibits the anodic dissolution of the metal [14 -15].

Inhibitor \# 2 can be considered as a promising component in the development of new inhibitory compositions for the protection of metals against biocorrosion caused by SRB. Sulfur reducing bacteria (SRB) are environmentally hazardous because they have the strongest corrosion properties among soil microorganisms. As a result of their high activity, growth and multiplication, the metal fracture can begin suddenly and lead to the formation of through perforations with the leakage of transported products and the pollution of the environment. To prevent such emergencies, it is necessary to use insulating coatings modified by corrosion inhibitors with biorefractory properties that resist SRB in soil locations. To protect the gas pipelines from microbial corrosion caused by SRB, the following design of the insulating coating is proposed: primer modified mastic - insulating tape. Primer that contains an inhibitor is applied to the cleaned surface of the pipeline. After the primer dries up, a mastic modified with an inhibitor, which exhibits bactericidal properties against $\mathrm{SRB}$, is applied on top of it. And an insulating tape is applied above the mastic. 


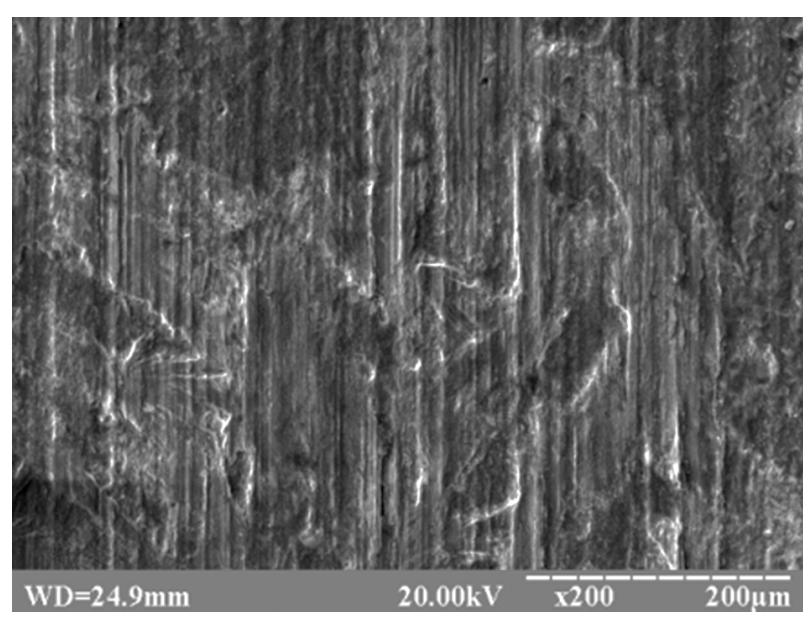

a)

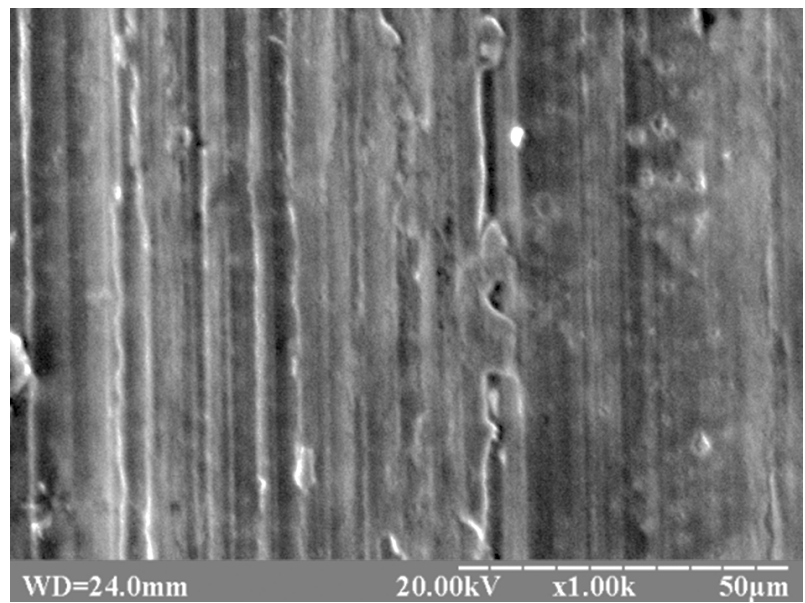

c)

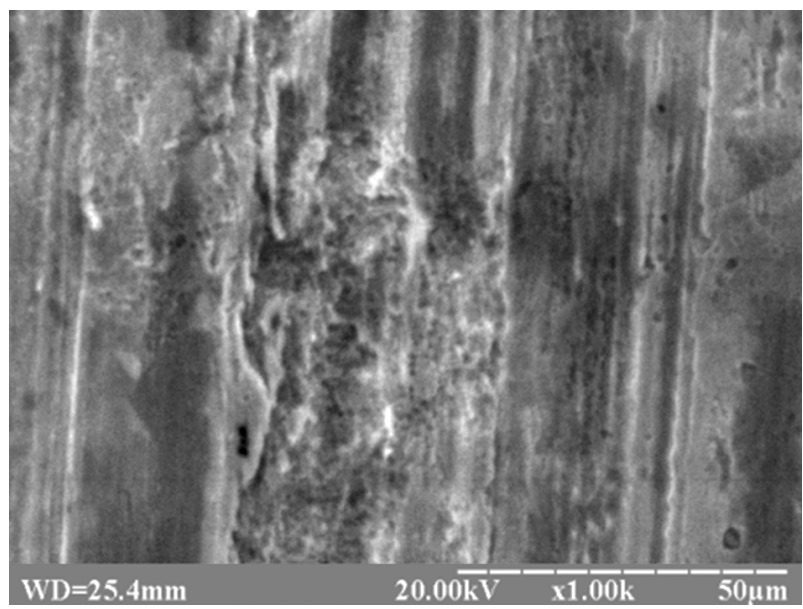

b)

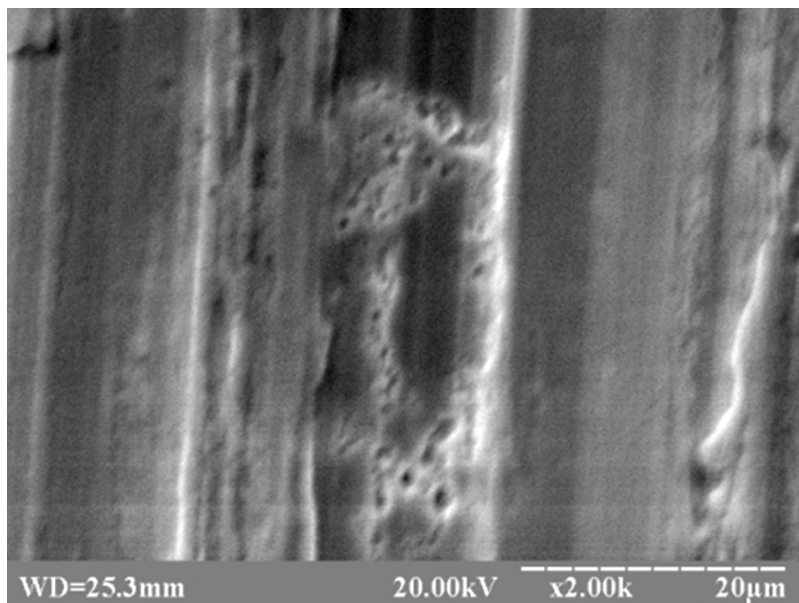

d)

Fig. 4. Morphology of the surface of specimens from steel 17G1S-U subjected to the effect of biocorrosion in different media: a) Postgate's B medium + SRB + inhibitor \# 1-0.5\%; b) Postgate's B medium + SRB + inhibitor \# 1-1.0\%; c) Postgate's B medium + SRB + inhibitor \# 2-0.5\%; d) Postgate's B medium + SRB + inhibitor \# 2-1.0\%

Obr. 4. Morfologie napadení vzorků v různých prostředích: a) Postgate $B$ medium s prídavkem SRB a $0,5 \%$ inhibitoru 1 ; b) Postgate $B$ medium s prídavkem SRB a 1,0\% inhibitoru 1; c) Postgate B medium s prídavkem SRB a 0,5\% inhibitoru 2; d) Postgate $B$ medium s prídavkem SRB a 1,0\% inhibitoru 2

\section{CONCLUSIONS}

The basic regularities are established in the variation of the corrosion rate of specimens from steel $17 \mathrm{G} 1 \mathrm{~S}-\mathrm{U}$ in the presence of organic inhibitors in the sterile Postgate's B medium, which were inoculated with SRB bacteria. The influence of the inhibitor nature on the degree of protection of steel specimens with the development of anaerobic corrosion under the influence of SRB is evaluated. The bactericidal properties of inhibitor \# 2 and the high protective effect from microbial corrosion caused by SRB are established. The physical-mechanical interpretation of the relief morphology of the investigated specimens under different modes of biocorrosion effect was proposed.

\section{REFERENCES}

1. Booth G. H. 1964. Sulphur bacteria in relation to corrosion, J. Appl. Bacteriol., 1964, 27,174-181.

2. Liang C., Wang H. and Huang N. Effects of Sulphatereducing bacteria on corrosion behaviour of 2205 duplex stainless steel, J. Iron. Steel. Res. 2014, 21, 444-450.

3. Mansfeld F. The interaction of bacteria and metal surfaces. Electrochim. Acta 2007, 52, 7670-7680.

4. Davey M. E. Microbial biofilms: from ecologyto molecular genetics, Microbiol. Mol. Biol. Rev. 2000, 64 (9), 847-867.

5. Hamilton W. A. Sulfate-reducing bacteria and anaerobic corrosion, Ann. Rev. Microbiol. 1985, 39, 195-217.

6. Antony P. J., Singh Raman R. K., Mohanram R., Kumar P. Influence of thermal aging on sulfate-reducing bacteria (SRB)-influenced corrosion behaviour of 2205 duplex stainless steel, Corros. Sci. 2008, 50, 1858-1864. 
7. Zeikus J. G., Dawson M. A., Thompson T. E., Ingvorsen K., Hatchikian E. C. Microbial Ecology of Volcanic Sulphidogenesis: Isolation and Characterization of Thermodesulfobacterium commune gen. nov. and sp. nov., Microbiology 1983, 129, 1159-1169.

8. Usher K. M., Kaksonen A. H., Cole I., Marney D. Critical review: Microbially influenced corrosion of buried carbon steel pipes, Int. Biodeterioration and Biodegradation 2014, 93, 84-106.

9. Chen X., Wang G., Gao F., Wang Y., He C. Effects of sulphate-reducing bacteria on crevice corrosion in X70 pipeline steel under disbonded coatings, Corros. Sci. 2015, 101, 1-11.

10. Rasol R. M., Noor N. M., Din M. M. Effect of temperature in SRB growth for oil and gas pipeline, Indian J. Sci. Technol. 2015, 8, 1-7.

11. Polutrenko M. S., Maruschak P. O., Prentkovskis O. The role of the biological factor in the corrosion damage of the metal of undergrund oil and gas pipelines, Proc. of the $20^{\text {th }}$ Int. Conf. «Transport Means» (October 5-7, Juodkrante, Lithuania), 2016, 424-427.
12. DSTU 3291-95 Methods for assessing biocorrosion activityof soils and to detect the presence of microbialcorrosion on the surface of underground metal constructions, Kyiv, «Derzhstandart Ukrainy», 1996, 28 p. (in Ukrainian)

13. DSTU 3999-2000 Protective coatings are polymeric, oilbituminous and coal-based. Methods of laboratory testing for bioresistance, Kyiv, «Derzhstandart Ukrainy», 2000, 16 p. (in Ukrainian)

14. Polutrenko M., Pilyashenko-Novokhatny A. Effect of nitrogenous corrosion inhibitors on the growth and activity of sulfur cycle bacteria, Chemistry and Chemical Technology 2013, 7 (4), 471-475.

15. Polutrenko M., Kryzhanivskyi Ye., PilyashenkoNovokhatnyi A., Peretyatko T. Peretyatko. The main aspects of microbiological protection of underground oiland-gas pipelines, J. of Hydrocarb. on Power Eng. 2013, 1 (1), 21-29. 